\title{
A role for Ras signaling in modulating mammalian aging by the GH/IGF1 axis
}

\author{
João Pedro de Magalhães \\ Integrative Genomics of Ageing Group, Institu te of Integrative Biology, University of Liverpool, Liverpool, UK
}

Commentary on: Consuelo Borrás et al. RasGrf1 deficiency delays aging in mice. Aging. 2011; 3: $262-276$.

Received: 4/10/11; Accepted: 4/19/11; Published: 4/19/11

Corresponding to: jp@senescence.info

(c) Magalhães. This is an open-access article distributed under the terms of the Creative Commons Attribution License, which permits unrestricted use, distribution, and reproduction in any medium, provided the original author and source are credited

The discovery that mutations in single genes can modulate aging was not only fascinating but it provided researchers with animal models with which to study aging in cohorts of different aging rates [1-2]. According to the GenAge database [3], at the time of writing, genetic manipulations in 68 genes have been shown to affect lifespan in mice. Among mouse genes in which mutations extend lifespan, a number are part of the growth hormone/insulin-like growth factor 1 (GH/IGF1) axis. As such, it is widely acknowledged that decreased GH/IGF1 signaling in mice can extend lifespan, while increased $\mathrm{GH}$ levels may accelerate aging [4-5]. Although the GH/IGF1axis is one of the major pathways regulating aging in mammals, its precise downstream mechanisms remain a subject of debate and scrutiny.

In this year's March issue of AGING, Borras et al. show that mice deficient in Rasgrf1, a guanine nucleotide-releasing factor for Ras, exhibit a significant increase $(\sim 20 \%)$ in average and maximum lifespan. This increase in lifespan was independent of cancer mortality and was accompanied by a retardation in age-related functional and physiological decline [6]. Ras homologues have been associated with lifespan modulation in yeast [7], so it seems that Ras signaling is another example of an evolutionary conserved pathway modulating aging. Rasgrfl is unique among Ras family members, however, as it is only expressed in a few specific tissues, in particular in pancreatic $\beta$-cells and in some regions of the brain. Thus far, Rasgrf1 has been primarily associated with learning and memory [6, 8-9].
Because of its expression in the brain, Rasgrfl has been shown to regulate the synthesis and release of $\mathrm{GH}$, and previous studies showed that Rasgrfl deficient mice have lower levels of GH [9-10]. In line with these previous studies, and given that GH impacts on IGF1 levels, Rasgrf1 deficient mice showed lower IGF1 levels [6]. Decreased GH/IGF1 signaling results in stunted growth and reduced adult body size, which has been associated with life-extension in numerous models [11]. Borras et al. and other authors also observed that Rasgrfldeficient mice are smaller than controls [6, 910]. Therefore, it is likely that decreased GH/IGF1 signaling is the mechanism by which Rasgrfl impacts on aging. Changes in GH/IGH1 have also been hypothesized to be related to the mechanisms of caloric restriction [4-5], which is in line with the observation by Borras et al., that Rasgrf1 deficient mice have metabolic profiles similar to mice under caloric restriction.

Because Rasgrf1 mutants have altered GH/IGF1 signaling, I had predicted that they would be long-lived [12]. Moreover, it was reported that bi-maternal mice are long-lived and, because Rasgrflis an imprinted gene expressed from the paternal allele in neonates, it is possible that bi-maternal mice are long-lived due to Rasgrf1 effects [12-13]. Although conducted in different labs and strains, bi-maternal mice had a similar increase in average lifespan (28\%), though a more modest increase in maximum lifespan $(\sim 5 \%)$.

Rasgrf1 deficient mice are therefore another model to study the modulation of aging by the GH/IGF1 axis. Interestingly, mice expressing Rasgrfl from both alleles have increased body size and higher IGF1 levels [9]. 
Although the lifespan of these animals is unknown, they could be seen as a complementary model to the Rasgrf1 knock-outs. Consequently, since they are available with both increased GH (biallelic Rasgrf1 mice) and decreased GH levels (Rasgrfl knock outs), the different Rasgrf1 mutant mice may be an excellent new model to study aging and its modulation by the GH/IGF1 axis.

\section{REFERENCES}

1. de Magalhaes JP, Cabral JA, Magalhaes D. The influence of genes on the aging process of mice: a statistical assessment of the genetics of aging. Genetics 2005; 169:265-274.

2. Ladiges $W$, Van Remmen $H$, Strong $R$, Ikeno $Y$, Treuting $P$, Rabinovitch $\mathrm{P}$, Richardson A. Lifespan extension in genetically modified mice. Aging Cell 2009; 8:346-352.

3. de Magalhaes JP, Budovsky A, Lehmann G, Costa J, Li Y, Fraifeld V, Church GM. The Human Ageing Genomic Resources: online databases and tools for biogerontologists. Aging Cell 2009; 8:65-72.

4. Berryman DE, Christiansen JS, Johannsson G, Thorner MO, Kopchick JJ. Role of the GH/IGF-1 axis in lifespan and healthspan: lessons from animal models. Growth Horm IGF Res 2008; 18:455-471.

5. de Magalhaes JP. Open-minded scepticism: inferring the causal mechanisms of human ageing from genetic perturbations. Ageing Res Rev 2005; 4:1-22.

6. Borras C, Monleon D, Lopez-Grueso R, Gambini J, Orlando L, Pallardo FV, Santos E, Vina J, Font de Mora J. RasGrf1 deficiency delays aging in mice. Aging (Albany NY) 2011; 3:262-276.

7. Lin SJ, Defossez PA, Guarente L. Requirement of NAD and SIR2 for life-span extension by calorie restriction in Saccharomyces cerevisiae. Science 2000; 289:2126-2128.

8. Brambilla R, Gnesutta N, Minichiello L, White G, Roylance AJ, Herron CE, Ramsey M, Wolfer DP, Cestari V, Rossi-Arnaud C, Grant SG, Chapman PF, Lipp HP, Sturani E, Klein R. A role for the Ras signalling pathway in synaptic transmission and long-term memory. Nature 1997; 390:281-286.

9. Drake NM, Park YJ, Shirali AS, Cleland TA, Soloway PD. Imprint switch mutations at Rasgrf1 support conflict hypothesis of imprinting and define a growth control mechanism upstream of IGF1. Mamm Genome 2009; 20:654-663.

10. Itier JM, Tremp GL, Leonard JF, Multon MC, Ret G, Schweighoffer F, Tocque B, Bluet-Pajot MT, Cormier V, Dautry F. Imprinted gene in postnatal growth role. Nature 1998; 393:125126.

11. de Magalhaes JP, Faragher RG. Cell divisions and mammalian aging: integrative biology insights from genes that regulate longevity. Bioessays 2008; 30:567-578.

12. de Magalhaes JP. Paternal genome effects on aging: evidence for a role of Rasgrf1 in longevity determination? Mech Ageing Dev 2011; 132:72-73.

13. Kawahara $\mathrm{M}$, Kono $\mathrm{T}$. Longevity in mice without a father. Hum Reprod 2010; 25:457-461. 